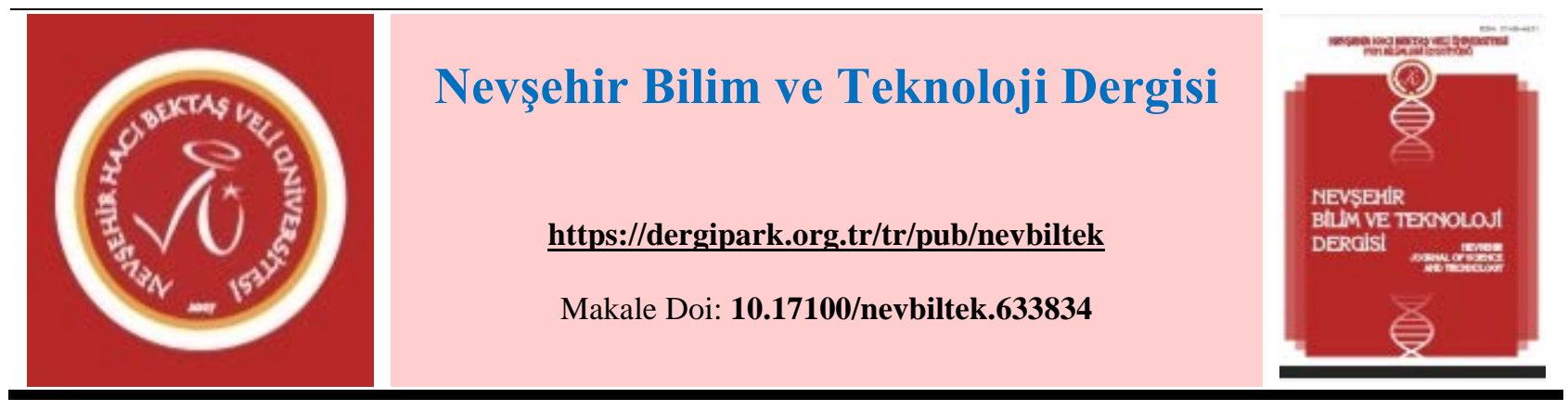

\title{
Slip Dökümle Üretilmiş Yunan Kırmızı Çamur Bünyelerin Sinterleme Özellikleri
}

\author{
Nermin DEMIRKOL ${ }^{1}$, Vildan SAMANCI ${ }^{2}$ \\ ${ }^{1}$ Kocaeli Üniversitesi, Değirmendere Ali Özbay MYO, Seramik, Cam \& Çinicilik Prog., Kocaeli \\ ORCID ID: 0000-0001-9088-023X \\ ${ }^{2}$ Kocaeli Üniversitesi, Değirmendere Ali Özbay MYO, Seramik, Cam \& Çinicilik Prog., Kocaeli \\ ORCID ID:0000-0003-2891-6865
}

Öz

Kırmızı çamur, alümina üretimi için kostik sodalı boksit cevherlerinin öğütülmesinde oluşan katı atık artığıdır. Dünyada birkaç kırmızı çamur kaynağı vardır. Bu çalı̧̧manın amacı, slip dökümle üretilmiş Yunan kırmızı çamur bünyelerin sinterleme koşullarını ve teknolojik özelliklerini belirlemektir. Kullanılan kırmızı çamurun kimyasal analizi XRF ile belirlendi. Slip dökülmüs numuneler hacimce \%40 katı içeriği ile hazırlandı ve ayrı ayrı 900, 950 ve $1000^{\circ} \mathrm{C}$ 'de 2 saat süre ile sinterlendi. Sinterleme ve teknolojik özellikler yoğunluk, pişme çekilmesi ve su emme ölçümleri ile tanımlandı. Yapısal karakterizasyon taramalı elektron mikroskobu (SEM) ve X-ışını çalışmaları ile gerçekleştirildi. En iyi yoğunluk, su emme, pişme çekilme değerleri $1000^{\circ} \mathrm{C}$ 'de sinterlenen Yunan kırmızı çamur bünye ile elde edildi. $1000^{\circ} \mathrm{C}$ 'de sinterlenen Yunan kırmızı çamur bünye üzerine artistik sır uygulandı. Sır-bünye etkileşimi tanımlandı.

Anahtar Kelimeler: sinterleme, kırmızı çamur, seramik, slip döküm, Yunan.

\section{Sintering Properties of Slip Casted Greek Red Mud Bodies}

\begin{abstract}
Red mud is a solid waste residue of the digestion of bauxite ores with caustic soda for alumina production. There are several red mud sources in the world. The aim of this study was to identify the sintering conditions and technological properties of slip casted Greek red mud bodies. Chemical analysis of used greek red mud was determined by XRF. Slip casted samples were prepared with 40 vol. \% solid content and sintered at 900,950 and $1000{ }^{\circ} \mathrm{C}$ for $2 \mathrm{~h}$, seperately. Sintering and technological properties were determined by measuring density, firing shrinkage and water absorption. Structural characterization was carried out with scanning electron microscopy (SEM) and X-ray diffraction studies. The best density, water absorption, firing shrinkage values were obtained with Greek red mud body sintered at $1000^{\circ} \mathrm{C}$. Artistic glaze was applied onto the Greek red mud bodies sintered at $1000^{\circ} \mathrm{C}$. Glaze-body interaction were determined.
\end{abstract}

Keywords: sintering, red mud, ceramic, slip casting, Greek. 


\section{Introduction}

Red mud is mostly collected from the Bayer process which uses sodium hydroxide to dissolve the aluminium silicate. Important efforts have been made by many researchers to improve properties of red mud and to reduce its environmental impacts. Red mud consists of valuable materials such as rare earth elements, titanium, aluminium. There are several red mud sources in the world [1].

It is estimated that annually 70 million tons of red mud is produced all over the World, with 0.7 million tons in Greece, 2 million tons in India, 30 million tons in Australia and approximately 30 million tons in China [2].

Red mud has red-brown color and very fine grain size distrubution. The characteristic fine grains of the red mud support the using it as additive in mortar and concrete [3].

Slip casting processes start by filling a mold with a ceramic slurry having a pourable consistency. The cast is produced when a physical, chemical, and/or thermal change causes the slurry to develop a yield strength. Solid casting produces a solid cast having the shape of the cavity of the mold. In drain casting, the cast forms adjacent to tle mold surface, and after the Wall has grown to the desired thickness, excess slurry is drained from the mold [4]. Recommended deflocculant:water ratio should be followed in the slip casting process [5].

Demir et.all investigated the effect of red mud on the properties of fired brick. Bricks have been manufactured by extrusion method with the addition of $0 \%$ (control series), $5 \%$ and $10 \%$ red mud into the Afyonkarahisar region brick clay. The brick samples have been fired in an electrically heated, furnace at 3 different temperatures between 800 and $1000^{\circ} \mathrm{C}$ with $100^{\circ} \mathrm{C}$ intervals. Physical and mechanical tests were performed on the fired samples. Fired samples with red mud waste additive were determined on increase on the compressive strength compared to the non-additive samples. The colours of red mud samples was much more red, compared to pure ones [3].

Demirkol investigated the technological and physical properties of dry pressed red mud bodies containing chamotte. Physical and technological properties were determined by measuring pore diameter, density, shrinkage and water absorption. Optimum chamotte addition to red mud bodies and optimum sintering temperature with high mechanical properties were determined with the study. The best density, water absorption, firing shrinkage and bending strength values were obtained with red mud containing $15 \mathrm{wt} . \%$ chamotte sample sintered at $1000^{\circ} \mathrm{C}$ as $2.94 \mathrm{~g} / \mathrm{cm}^{3}, 6.6 \%$ and 107 $\mathrm{MPa}$, respectively [6]

\section{Materials and Methods}

The red mud used in the present study was obtained as the Greek aluminum industry waste. The chemical analysis of red mud sample (performed by X-ray Fluorescence using a Panalytical Eagon 2 instrument at DPU Iltem Advanced Technologies Center) is presented in Table 1.

Greek red mud consists of mainly silica, alümina, magnesia, iron oxide, potassium oxide, calcia, sodium oxide, titania and trace elements as seen in Table 1.

Table 1. Chemical Analysis of Greek Red Mud.

\begin{tabular}{|c|c|c|c|c|c|c|c|}
\hline $\mathbf{S i O}_{2}$ & 45,56 & $\mathbf{K}_{2} \mathbf{O}$ & 4,59 & $\mathbf{S O}_{3}$ & 0,07 & SrO & 0,08 \\
\hline $\mathbf{A l}_{2} \mathbf{O}_{3}$ & 16,66 & $\mathbf{C a O}$ & 7,36 & $\mathbf{T i O}_{2}$ & 0,71 & $*$ L.I & 13,28 \\
\hline $\mathbf{F e} \mathbf{O}_{3}$ & 7,19 & $\mathbf{N a}_{2} \mathbf{O}$ & 0,98 & $\mathbf{P}_{\mathbf{2}} \mathbf{O}_{\mathbf{5}}$ & 0,14 & \\
\hline $\mathbf{M g O}$ & 3,23 & $\mathbf{Z r O}_{2}$ & 0,04 & $\mathbf{M n O}$ & 0,12 & \\
\hline
\end{tabular}

40 vol.\% solid content Greek red mud slip was prepared. Cylindirical rod shape strength measurement test specimens were prepared by slip casting. To do that particular slurry was poured in a cylindirical plaster of Paris mould (10 mm diameter by $80 \mathrm{~mm}$ length) and the amount of water absorbed by the mould walls were progressively replaced with slip until the whole wall was filled with the green cast specimen and solid rod was obtained. Slip casted samples were sintered at 900,950 and $1000^{\circ} \mathrm{C}$.

Water absorption test (EN ISO 10545-3), firing shrinkage (ASTM C326-09), and density measurements (using Archimedes rule) were performed to determine the physical and technological properties of the sintered samples. The water absorption values were calculated from weight differences between the dry sample $\left(\mathrm{m}_{1}\right)$ and impregnated with boiling water sample $\left(\mathrm{m}_{2}\right)$ (Eqs. 1$)$.

Water Absorption (\%) : ( $\left.\left(\mathrm{m}_{2}-\mathrm{m}_{1}\right) / \mathrm{m}_{1}\right) .100(1)$

Microstructures of the Greek red mud (GRM) samples sintered at 900 , 950 and $1000{ }^{\circ} \mathrm{C}$ were examined by scanning electron microscopy using NOVA SEM 650 scanning electron microscope.

XRD analysis were conducted on a PANalytical EMPYREAN X-ray diffractometer. 


\section{Results and Discussion}

Figure 1 exhibits the density values of Greek red mud bodies sintered at 900,950 and $1000^{\circ} \mathrm{C}$. Density increased with increasing sintering temperature. The highest density was obtained with the GRM sintered at $1000^{\circ} \mathrm{C}$ as $1,98 \mathrm{~g} / \mathrm{cm}^{3}$.

Figure 2 shows the firing shrinkage values of Greek red mud bodies (GRM) sintered between 900 and $1000^{\circ} \mathrm{C}$ with $50^{\circ} \mathrm{C}$ intervals. The firing shrinkage of Greek red mud body (GRM) varies from 3,97\% to 8,45\% at temperatures from $900^{\circ} \mathrm{C}$ to $1000^{\circ} \mathrm{C}$ (Figure 2), this variation is due to the increasing density and decreasing porosity with increasing sintering temperature.

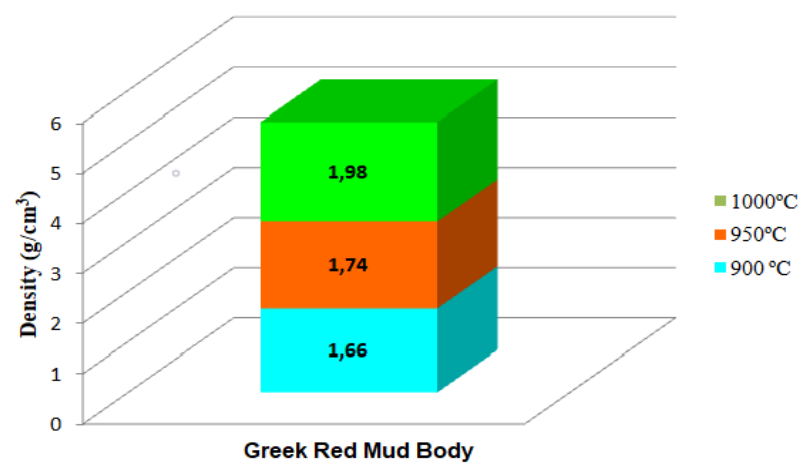

Figure 1. Density graphic of Greek Red Mud samples sintered at different sintering temperatures

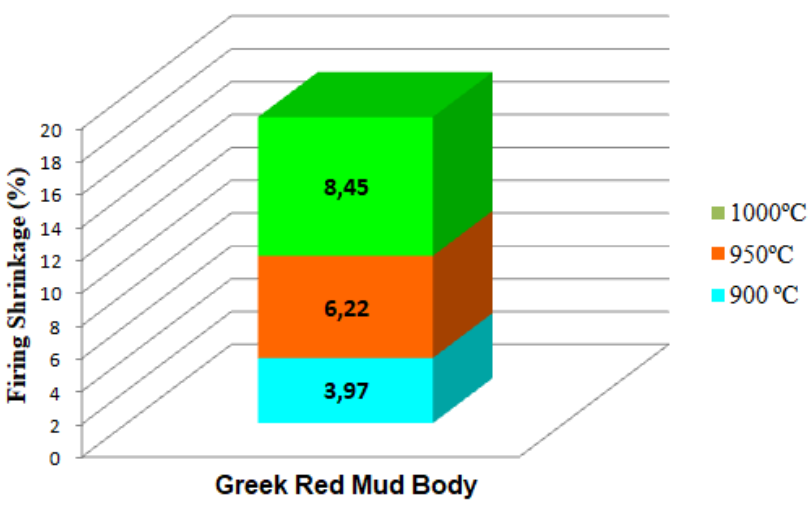

Figure 2. Firing Shrinkage graphic of Greek Red Mud samples sintered at different sintering temperatures

Figure 3 exhibits the water absorption results of Greek red mud at different sintering temperatures. Water absorption of the GRM decreased with increasing sintering temperature. When temperature increased, porosity of sample decreased and water absorption decreased because of low porosity.

Demirkol [6] worked on technological and physical properties of dry pressed red mud bodies containing chamotte. 5 wt\% chamotte added Turkish red mud body sintered at $1000^{\circ} \mathrm{C}$ showed density, water absorption and firing shrinkage values as $2.25 \mathrm{~g} / \mathrm{cm}^{3}, 9.9 \%$ and $9.8 \%$, respectively. Technological and physical properties of dry pressed Turkish red mud containing $5 \mathrm{wt} \%$ chamotte body sintered at $1000^{\circ} \mathrm{C}$ exhibited better results than Greek red mud body sintered at $1000^{\circ} \mathrm{C}$.

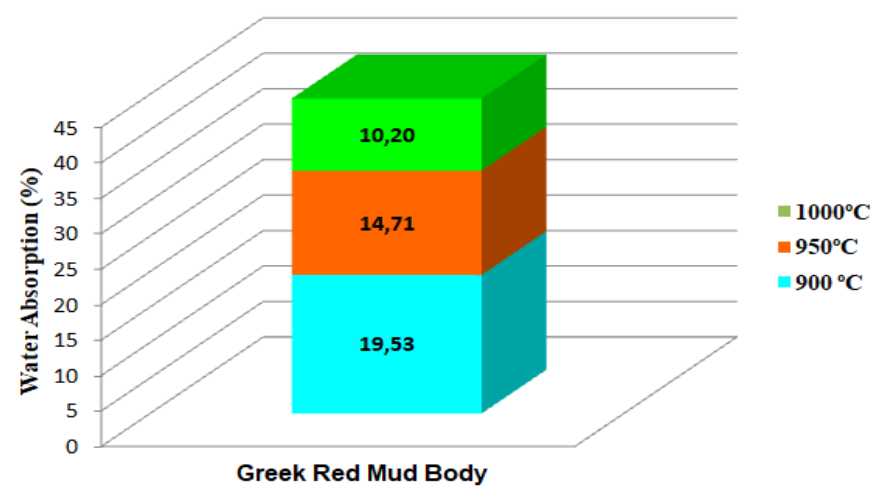

Figure 3. Water Absorption graphic of Greek Red Mud samples sintered at different sintering temperatures 
Fig.4 exhibits the microstructure of Greek red mud (GRM) sintered at (a) $900^{\circ} \mathrm{C}$ and (b) $1000^{\circ} \mathrm{C}$. The microstructure at $1000^{\circ} \mathrm{C}$ sintering temperature shows better densification and crystallinity due to better compaction with increasing sintering temperature as seen in Fig.4b.

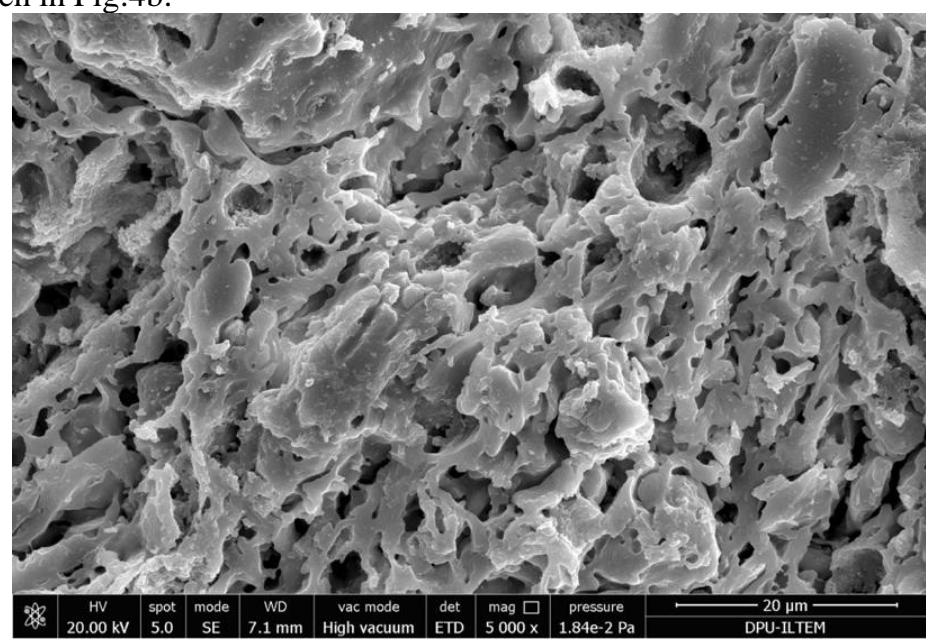

( a )

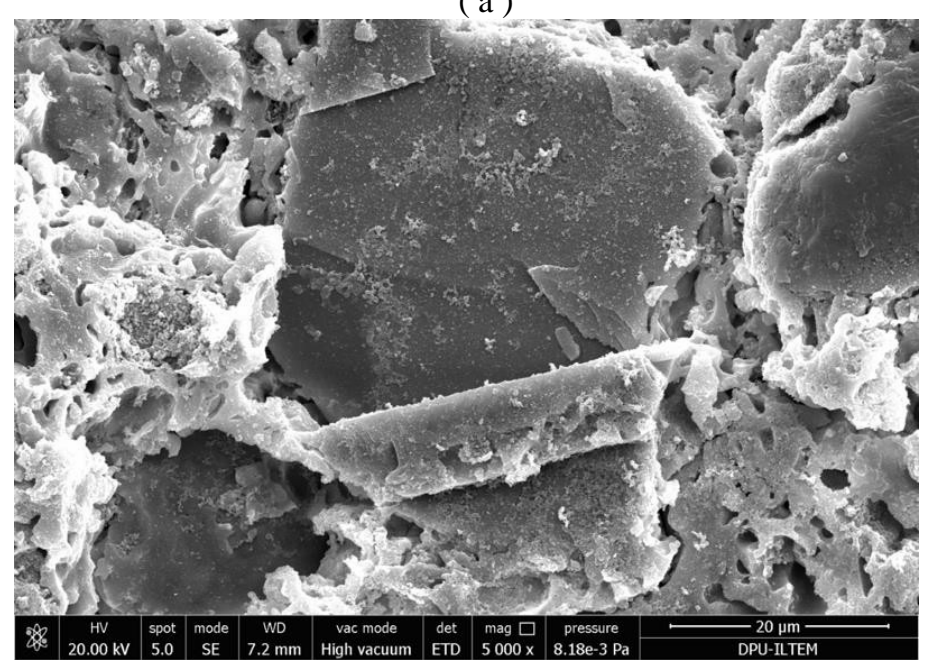

( b )

Figure 4. SEM images of Greek red mud samples sintered at different temperatures. (a) $900^{\circ} \mathrm{C}$ (b) $1000^{\circ} \mathrm{C}$

XRD diagrams of Greek red mud samples sintered at different sintering temperatures are given in Fig.5. Both samples include quartz, hematite, anorthite, orthoclase and akermanite-gehlenite in both sintering temperatures. Greek red mud (GRM) sintered at $1000^{\circ} \mathrm{C}$ (Fig.5b) shows sharper and more evident quartz and anorthite peaks than the Greek red mud (GRM) sintered at $900^{\circ} \mathrm{C}$ (Fig.5a).
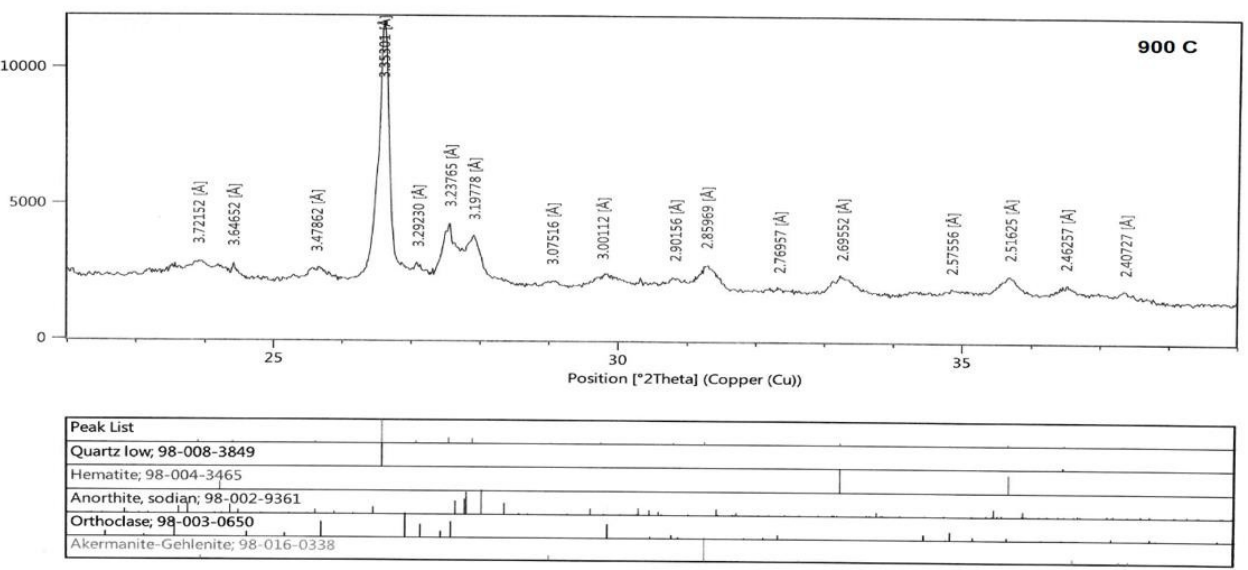

( a ) 
Nevşehir Bilim ve Teknoloji Dergisi (2019), 8(IMSMATEC Özel Sayı) 71-77

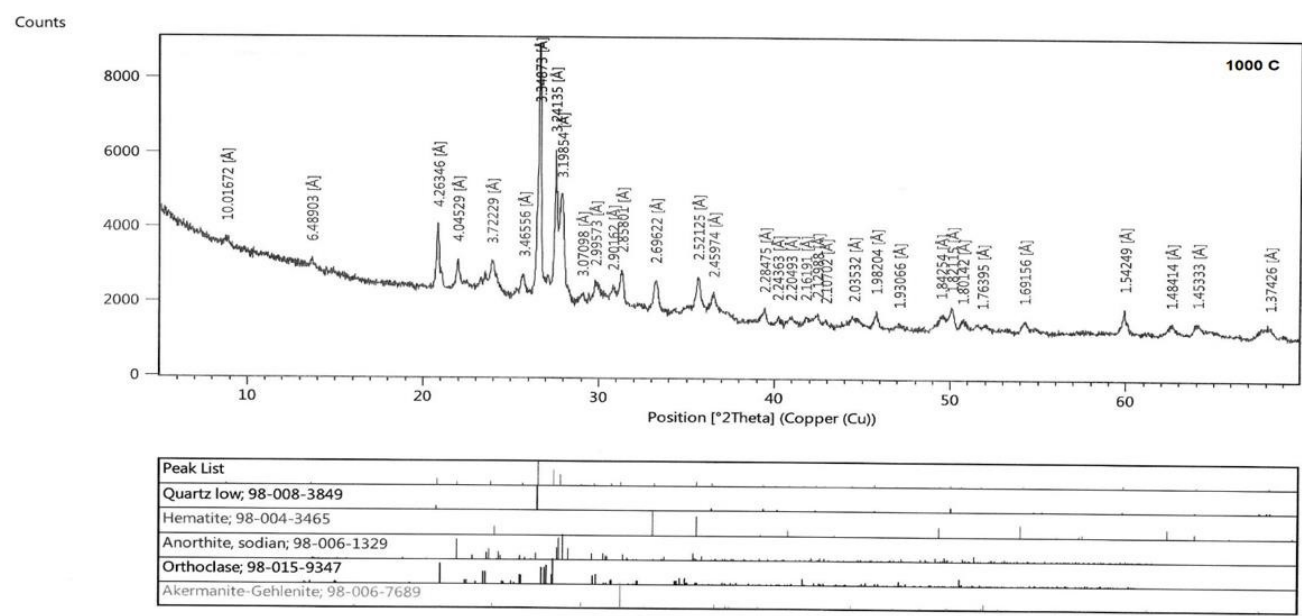

( b )

Figure 5. XRD diagrams of Greek red mud samples sintered at different temperatures. (a) $900^{\circ} \mathrm{C}$ (b) $1000^{\circ} \mathrm{C}$

Fig. 6 shows the glazed sample of GRM sintered at $1000^{\circ} \mathrm{C}$. Used artistic glaze recipe was given in Table 2. It includes red copper oxide as a colorant. Applied glaze includes high amount of $\mathrm{B}_{2} \mathrm{O}_{3}$.

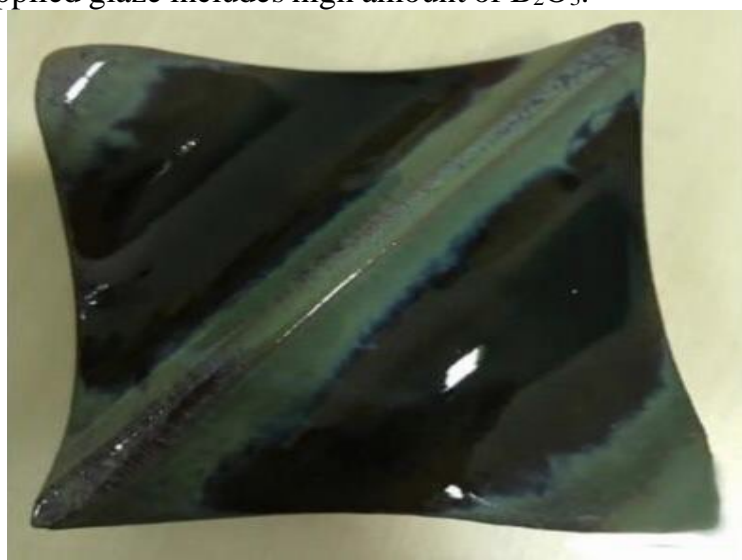

Figure 6. Glazed form of Greek red mud sample sintered at $1000^{\circ} \mathrm{C}$

Table 2. Artistic Glaze Recipe Used in Figure 6.

\begin{tabular}{cc} 
Raw Material & Percentage (\%) \\
\hline Borax & 46.64 \\
\hline Ulexite & 22.32 \\
\hline Sodium Feldspar & 11.87 \\
\hline Lithium Carbonate & 6.03 \\
\hline Rutile & 3.09 \\
\hline Quartz & 10.05 \\
\hline Red Copper Oxide & 3 \\
\hline
\end{tabular}

Glaze act as smooth, relatively thin glassy coating of ceramic body which is effectively bonded to its substrate. The main reason for the use of glazes as surface coatings of ceramic materials is their relatively high chemical resistance nd aesthetic aspects. Glazes and ceramic bodies are in close contact and react chemically and physically during firing [7]. The bodyglaze interaction is very good. The glaze adheres to the body without causing any errors. 


\section{Conclusions}

In this study, sintering and technological properties of Greek red mud bodies were examined. The findings of this study are concluded as follows:

1. Density and firing shrinkage values of slip casted Greek red mud (GRM) bodies increased with increasing sintering temperature.

2. The highest density and firing shrinkage values were obtained with GRM samples sintered at $1000^{\circ} \mathrm{C}$ as 1.98 $\mathrm{g} / \mathrm{cm}^{3}$ and $8.45 \%$, respectively.

3. Water absorption values of Greek red mud decreased with increasing sintering temperature because of increasing density.

4. The lowest water absorption value was obtained with GRM sintered at $1000^{\circ} \mathrm{C}$ as $10.20 \%$.

5. Greek red mud (GRM) sintered at $1000^{\circ} \mathrm{C}$ showed sharper and more evident quartz and anorthite peaks than GRM sintered at $900^{\circ} \mathrm{C}$.

6. The GRM ceramic body and glaze interaction is very good. The glaze adheres to the ceramic body easily.

7. Different kinds of glaze applications to the GRM ceramic body studies are going on.

8. Sintering and technological properties of slip casted Greek red mud showed lower properties than Turkish red mud containing chamotte and Kastamonu mud containing clay.

\section{References}

[1] Ziynan C., Yunlong Y.U.E., Ya Q.U., Sheng L.I.,Fengnion W.U. and Hongting L.I.U, Properties of Aluminosilicate Glasses Prepared by Red Mud with Various [Al2O3]/[CaO] Mass Ratios. Journal of Wuhan University of TechnologyMater.Sci.Ed.www.jwutms.net, 33(2), 363-367, 2018.

[2]Sutar H., Mishra S.C., Sahoo S.K., Chakraverty A.P. and Maharana H.S., Progress of Red Mud Utilization: An Overview. American Chemical Science Journal 4(3), 255-279, 2014.

[3]Demir I., Baspinar M.S. and Kahraman E., An Investigation Effect of Red Mud on the Properties of Fired Brick. Afyon Kocatepe University Journal of Science and Engineering, 14 QZ5785, 2014.

[4]Reed J.S., Principles of Ceramic Processing. A Wiley-Interscience Publication, John\&Wiley\&Sons, Inc. pp.492, 1995.

[5]Reijnders A., The Ceramic Process, European Ceramic Word Centre, A\&C Black Publishers Limited., pp 46.2005.

[6]Demirkol N.,Technological and Physical Properties of Dry Pressed Red Mud Bodies Containing Chamotte. Arabian Journal of Geosciences, 12:278, 2019.

[7] Kavanová M., Klouzková A. and Klouzek J., Characterization of the Interaction Between Glazes and Ceramic Bodies. Ceramics-Silikáty 61(3) 267-275, 2017.

\section{Genişletilmiş Özet}

\section{Giriş}

Kırmızı çamur çoğunlukla, alüminyum silikatı çözmek için sodyum hidroksit kullanan Bayer prosesinden toplanmaktadır. Pek çok araştırmacı tarafından kırmızı çamurun özelliklerini geliştirmek ve çevresel etkilerini azaltmak için önemli çabalar sarf edilmiştir. Kırmızı çamur, nadir toprak elementleri, titanyum, alüminyum gibi değerli malzemelerden oluşmaktadır.

Dünyada birçok kırmızı çamur kaynağı vardır. Tüm dünyada yıllık 70 milyon ton kırmızı çamur üretildiği tahmin edilmektedir. Bunun 0.7 milyon tonu Yunanistan’da, 2 milyon tonu Hindistan'da, 30 milyon tonu Avustralya'da ve yaklaşı 30 milyon tonu Çin’de üretilmektedir. Kırmızı çamur, kırmızımsı kahverengi renktedir ve çok ince tane boyut dağılımına sahiptir.

Slip döküm işlemleri, kalıbı dökülebilir bir kıvamda olan seramik sulu çamur karışımı ile doldurmakla başlamaktadır. Döküm, fiziksel, kimyasal ve/veya termal bir değişim slibin akma mukavemeti geliştirmesine neden olduğunda üretilmektedir. Kütle döküm, kalıp boşluğu şeklinde bir katı döküm üretmektedir. Boşaltmalı dökümde ise, döküm kalıp yüzeyine bitişik döküm formları oluşturur ve istenen et kalınlığına ulaştıktan sonra fazla döküm çamuru kalıptan 
boşaltılmaktadır.

Demir ve çalışma ekibi, ateş tuğlasının özellikleri üzerinde kırmızı çamurun etkisini araştırmışlardır. Afyonkarahisar yöresi tuğla kili içerisine \%0 (kontrol serisi), ağ. \%5 ve ağ.\%10 kırmızı çamur ilavesi ile ekstrüzyonla tuğla üretilmiştir. Tuğla numuneleri, $100^{\circ} \mathrm{C}$ aralıklarla $800-1000^{\circ} \mathrm{C}$ arasında 3 farklı sıcaklıkta elektrikli firında sinterlenmiştir. Sinterlenen numuneler üzerinde fiziksel ve mekanik testler yapıldı. Kırmızı çamur içeren numunelerin ilavesizlere göre basma mukavemetini arttırdığ 1 sonucuna varılmıştır.

Demirkol kuru presleme metodu ile üretilen şamot içeren kırmızı çamur bünyelerin teknolojik ve fiziksel özelliklerini araştırmıştır. Fiziksel ve teknolojik özellikler por çapı, yoğunluk, çekilme ve su emme ölçümleri ile tanımlandı. Bu çalışma ile, kırmızı çamur bünyelere optimum şamot ilavesi ve yüksek mekanik özellikler için optimum sinterleme sıcaklığı belirlendi. En iyi yoğunluk, su emme, pişme çekilmesi ve eğme mukavemeti değerleri $1000^{\circ} \mathrm{C}$ 'de sinterlenen ağ. \%15 şamot içeren kırmızı çamur numune ile sırasıyla 2.94 g/cm³, \%6.6 ve $107 \mathrm{MPa}$ olarak elde edildi.

\section{Method}

Mevcut çalışmada kullanılan kırmızı çamur, Yunan alüminyum endüstrisi atığı olarak elde edildi. Yunan kırmızı çamuru (GRM) temel olarak silika, alümina, magnezya, demir oksit, potasyum oksit, kalsiyum oksit, sodyum oksit, titanya ve eser elementlerden oluşmaktadır.

Hacimce \%40 katı içerikli Yunan kırmızı çamurundan oluşan slip hazırlandı. Slip döküm metoduyla silindirik çubuk şekilli mukavemet ölçüm test numuneleri hazırlandı.

Numuneler 900, 950 ve $1000^{\circ} C^{\prime}$ de sinterlendi. Su emme testi (EN ISO 10545-3), pişme çekilmesi (ASTM C326-09) ve

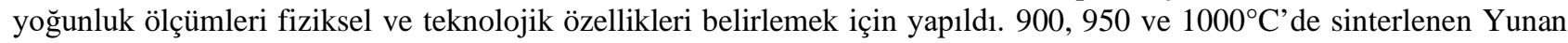
kırmızı çamur (GRM) numunelerin mikroyapıları NOVA SEM 650 taramalı elektron mikroskobu kullanılarak belirlendi. XRD analizleri PANalytical EMPYREAN X-ışını difraktometresi ile incelendi.

\section{Results and Discussion}

$\mathrm{Bu}$ çalışma sonucunda, slip dökülmüş Yunan kırmızı çamur (GRM) bünyelerin yoğunluk ve pişme çekilmesi değerleri artan sinterleme sıcaklığı ile arttı. En yüksek yoğunluk ve pişme çekilmesi değerleri $1000^{\circ} \mathrm{C}^{\prime}$ de sinterlenen GRM numuneler ile sırasıyla $1.98 \mathrm{~g} / \mathrm{cm}^{3}$ ve $\% 8.45$ olarak elde edildi. $900^{\circ} \mathrm{C}$ 'den $1000^{\circ} \mathrm{C}^{\prime}$ ye değişen sicaklıklarda pişme çekilmesi \%3.97'den \%8.45'e değişmektedir. Bu değişim, sinterleme sıcaklığı ile artan yoğunluk ve azalan poroziteden kaynaklanmaktadir.

GRM bünyelerin su emme değerleri artan yoğunluktan dolayı azaldı. En düşük su emme değeri $1000^{\circ} \mathrm{C}^{\prime}$ de sinterlenen GRM numuneler ile \%10.20 olarak elde edildi. Her iki numune de, her iki sinterleme sıcaklığında kuvars, hematit, anortit, ortoklas ve akermanit-gehlenit içermektedir. $1000^{\circ} \mathrm{C}$ 'de sinterlenen GRM, $900^{\circ} \mathrm{C}$ 'de sinterlenene göre daha keskin ve belirgin pikler gösterdi.

$1000^{\circ} \mathrm{C}$ 'de sinterlenen GRM numunelerin mikroyapısı, artan sinterleme sıcaklığg ile daha iyi paketlenmeden dolayı, daha iyi yoğunlaşma ve kristallik göstermiştir.

$1000^{\circ} \mathrm{C}$ 'de sinterlenen GRM numunelere borlu, renklendirici oksit olarak ta kırmızı bakır oksit içeren bir sır reçetesi uyguland 1 ve $1000^{\circ} \mathrm{C}$ 'de sinterlendi. Sır, altlığa etkili bir şekilde bağlanan, seramik bünyenin pürüzsüz, görece olarak camsı bir kaplaması olarak görev görür. Sırların seramik malzemelerin yüzey kaplamaları olarak kullanılmasının ana nedeni, nispeten yüksek kimyasal dayanımları ve estetik görünümleridir. Sırlar ve seramik bünyeler birbiri ile yakın temastadır ve sinterleme esnasında kimyasal ve fiziksel olarak reaksiyona girmektedir. Bu çalışmada uygulanan sır herhangi bir hataya neden olmadan bünye ile birleşmiştir. 